\title{
Komposisi Nutrisi dan Kandungan Pigmen Fotosintesis Tiga Spesies Alga Merah (Rhodophyta sp.) Hasil Budidaya
}

\author{
Salnida Yuniarti Lumbessy*, Dewi Nur’aeni Setyowati, Alis Mukhlis, \\ Dewi Putri Lestari, Fariq Azhar \\ Program Studi Budidaya Perairan, Fakultas Pertanian, Universitas Mataram \\ JI. Majapahit Nomor 62, Mataram 83125 Indonesia \\ *Corresponding author, e-mail: salnidayuniarti@unram.ac.id
}

\begin{abstract}
ABSTRAK: Berbagai alga merah memiliki potensi nilai nutrisi dan biopigmen yang dapat dimanfaatkan untuk menambah nilai manfaat serta nilai jual rumput laut. Penelitian ini bertujuan untuk mengetahui komposisi kimia dan kandungan pigmen fotosintesis pada tiga spesies alga merah, yaitu Eucheuma cottonii, Eucheuma spinosum dan Eucheuma striatum yang dibudidayakan di Perairan Sreweh, Lombok Timur, NTB. Ketiga sampel tersebut diambil dalam bentuk segar dari hasil budidaya selama 42 hari. Sampel dianalisa komposisi nutrisi dengan menggunakan uji proksimat sedangkan pigmen fotosintesis diuji dengan menggunakan spktrofotometer. Hasil analisa menunjukkan bahwa E. cottonii mempunyai kandungan lemak $(5,77 \%)$, serat $(15,22 \%)$, karbohidrat $(47,36 \%)$ dan pigmen fikoeritrin $(42,88 \mathrm{mg} / \mathrm{g})$ yang tertinggi. Alga merah $E$. spinosum mempunyai kadar air yang tertinggi $(29,72 \%)$ dan alga merah $E$. striatum mempunyai kandungan protein $(4,51 \%)$, abu $(32,49 \%)$, klorofil a $(30,41 \mathrm{mg} / \mathrm{g})$ dan klorofil b $(54,95$ $\mathrm{mg} / \mathrm{g}$ ) yang tertinggi. Ketiga spesies alga merahi ini mempunyai potensi sebagai sumber bahan pangan yang dapat meningkatkan nilai nutrisi dan kesehatan pada manusia maupun hewan sehingga dapat memberikan kontribusi sebagai sumber pangan fungsional.
\end{abstract}

Kata Kunci: Komposisi nutrisi; Pigmen Fotosintesis; Alga merah

\section{Nutrient Composition and Photosynthetic Pigment Content of Three Red Algae (Rhodophyta sp.) Cultivated}

ABSTRACT: Various red algae have potential nutritional and biopigment values that can be utilized to add value and sale value of seaweed. This study aims to determine the chemical composition and content of photosynthetic pigments in three species of red algae, namely Eucheuma cottonii, Eucheuma spinosum and Eucheuma striatum cultivated in Sreweh Waters, East Lombok, NTB. The three samples were taken in fresh form the cultivation for 42 days. The nutritional composition of the sample was analyzed using the proximate test while the photosynthetic pigments were tested using a spectrophotometer. The analysis showed that $E$. cottonii had the highest content of fat $(5.77 \%)$, fiber $(15.22 \%)$, carbohydrates $(47.36 \%)$ and phicoerythrin pigment $(42.88 \mathrm{mg} / \mathrm{g})$. Red algae $E$. spinosum has the highest air content $(29,72 \%)$ and red algae $E$. striatum has protein content $(4.51 \%)$, ash $(32.49 \%)$, chlorophyll a $(30.41 \mathrm{mg} / \mathrm{g})$ and chlorophyll b $(54.95 \mathrm{mg} / \mathrm{g})$ the highest. These three species of red algae have potential as a source of fodd ingredients that can increase nutritional value and health in humans and animals, so that they can contribute as a source of functional food.

Keywords: Nutritional composition, Photosynthetic Pigments, Red Algae

\section{PENDAHULUAN}

Alga merah (Rhodophyta) merupakan kelompok rumput laut dengan jumlah spesies paling banyak, yaitu sekitar 4000 jenis (Lee, 2008). Alga merah termasuk jenis rumput laut berpotensi ekonomis tinggi, mengandung vitamin, mineral, serat, natrium, kalium, dan senyawa bioaktif yang berupa hasil metabolit sekunder, dan nutrisi yang paling penting adalah pigmen (Holdt and Kraan, 2011 ; Fretes et al.,2012). Eucheuma sp. merupakan salah satu spesies alga merah yang banyak 
dibudidayakan dan bernilai ekonomis karena manfaat pikokoloidnya yang besar yaitu sebagai sumber karaginan dan agar serta teknik budidayanya yang relatif mudah dan murah.

Komposisi nutrisi pada rumput laut sangat bervariasi tergantung pada spesies, tingkat kedewasaan, kondisi lingkungan seperti, kualitas air laut dan cahaya (Ortiz et al., 2006; Zawawi et al., 2014,). Perubahan kondisi ekologi sangat mempengaruhi kandungan nutrisi pada rumput laut (Benjama dan Masniyom, 2012). Beberapa penelitian tentang kandungan nutrisi pada Eucheuma $s p$. yang diperoleh pada beberapa lokasi perairan di duniatelah dilakukan (Kumar and Kaladarn, 2007; Siddique et al, 2013; Nurjannah et al., 2017; Xiren dan Aminah, 2017; Diharmi dan Irasari, 2020; Lumbessy et al., 2019). Hasil penelitian tersebut menunjukkan bahwa kandungan nutrisi Eucheuma sp sangat bervariasi pada berbagai perairan walaupun merupakan spesies yang sama.

Selain kandungan nutrisi yang kaya, Eucheuma sp. juga kaya akan pigmen fotosintesis dan pigmen aksesoris lainnya, yaitu klorofil a, $\alpha$-karoten, $\beta$-karoten, fikobilin, neozanthin dan zeaxanthin. (Bixler dan Porse 2011 ; Madhavarani dan Ramanibai, 2014). Klorofil dan fikoeritrin merupakan pigmen yang dapat dimanfaatkan sebagai produk pigmen alami yang berperan sebagai suplemen kesehatan. Beberapa penelitian tentang pigmen klorofil dan fikoeritrin pada rumput laut merah telah dilakukan (Reeta dan Kulandaivelu, 2000; Aguilera et al., 2002; Gudrun dan Wincke, 2005; Lee, 2008; Merdekawati dan Susanto, 2009 ; Naguit dan Tisera, 2009; Sarojini dan Narayanan, 2009 ; Schmidt et al., 2010 ; Vanitha dan Chandra, 2012). Hasil penelitian ini menunjukkan bahwa warna thallus yang bervariasi disebabkan karena adanya komposisi pigmen yang terdiri dari klorofil a, klorofil d dan fikobiliprotein. Komposisi pigmen pada rumput laut merah yang sangat bervariasi ini dapat menjadi salah satu peluang untuk usaha eksplorasi biopigmen rumput laut yang mampu menambah nilai manfaat serta nilai jual rumput laut.

Perairan Sreweh merupakan salah satu wilayah perairan di Indonesia yang sesuai untuk budidaya Eucheuma sp. Peraiarn Sreweh terletak di Kabupaten Lombok Timur, Nusa Tenggara Barat (NTB). Beberapa jenis Eucheuma sp. yang sering dibudidayakan adalah Eucheuma cottonii, Eucheuma spinosum dan Eucheuma striatum. Belum banyak informasi mengenai kandungan nutrisi dan pigmen fotosintesis pada ketiga spesies yang dibudidayakan di Perairan Sreweh tersebut. Oleh karena itu penelitian ini bertujuan untuk mengetahui komposisi kimia dan kandungan pigmen fotosintesis pada tiga spesies alga merah yang dibudidayakan di Perairan Sreweh.

\section{MATERI DAN METODE}

Alga merah yang digunakan untuk penelitian ini terdiri atas tiga spesies, yaitu Eucheuma cottonii, Eucheuma spinosum dan Eucheuma striatum. Ketiga sampel tersebut diambil dalam bentuk segar dari hasil budidaya petani rumput laut selama 42 hari dengan metode long line di Perairan Sreweh, Lombok Timur, Nusa Tenggara Barat (NTB) pada bulan Otober - November. Selanjutnya ketiga jenis alga merah tersebut dimasukkan dalam plastik polybag dan disimpan dalam es curai serta ditempatkan di cool box. Sampel segera dibawa ke laboratorium untuk dianalisa komposisi kimianya serta kandungan klorofil dan fikoeritrin.

Pengujian proksimat meliputi kadar air, kadar abu, protein, lemak kasar,serat kasar dan karbohidratdilakukan berdasarkan metode standar (AOAC, 2006). Analisis kadar air dan kadar abu dengan menggunakan metode Thermogravimetri, analisis kadar protein menggunakan metodeKjeldahl, analisis kadar lemak dengan metode soxhlet. Sementara kadar karbohidrat dihitung dengan menggunakan metode by difference.

Pengukuran pigmen fotosintesis dilakukan dengan cara sampel alga merah dihaluskan dengan menggunakan blender kemudian ditimbang sebanyak $2 \mathrm{~g}$ dan digerus menggunakan mortar. Sampel ditambahkan $10 \mathrm{ml} 100 \%$ aceton (untuk klorofil) dan $10 \mathrm{ml} 0.1 \mathrm{M}$ buffer phospat (untuk fikoeritrin). Sampel dimasukkan dalam tabung reaksi kemudian disentrifuge dan disaring. Sampel hasil sentrifuge diukur absorbansinya dengan menggunakan spektrofotometer pada panjang gelombang $664 \mathrm{~nm}$ dan 647nm untuk klorofil a serta 592, 564 and $455 \mathrm{~nm}$ untuk fikoeritrin.

Konsentrasi klorofil dihitung berdasarkan persamaan Sterman (1988) sedangkan konsentrasi fikoeritrin dihitung berdasarkan persamaan Beer dan Eshel (1985). Konsentrasi pigmen per gram rumput laut dihitung berdasarkan persamaan Naguit dan Tisera (2009). 
Data proksimat serta pigmen klorofil dan fikoeritrin yang diperoleh selanjutnya dianalisis secara deskriptif dan dipresentasikan dalam nilai rata-rata dan standar deviasi $( \pm S D)$ dalam bentuk Tabel atau Gambar. Data diolah menggunakan Microsoft exel secara deskriptif.

\section{HASIL DAN PEMBAHASAN}

Alga atau rumput laut merupakan tumbuhan tingkat rendah yang tidak memiliki perbedaan susunan kerangka seperti akar, batang dan daun, keseluruhan bagian tubuh disebut thallus (Ferawati et al., 2014). Secara taksonomi, alga/rumput laut termasuk dalam divisi Thallophyta. Sampel alga merah (Rhodophyta) yang digunakan dalam penelitian ini teridentifikasi sebagai Eucheuma cottonii, Eucheuma spinosum dan Eucheuma striatum (Gambar 1).

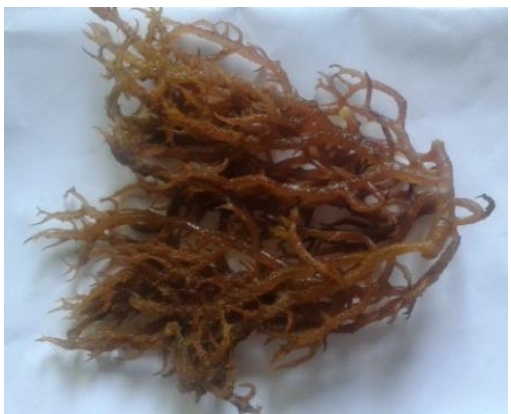

Eucheuma cottonii

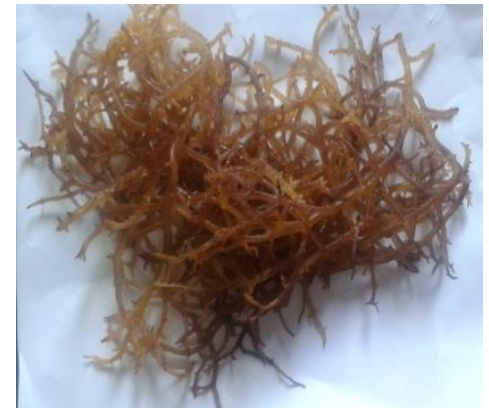

Eucheuma spinosum

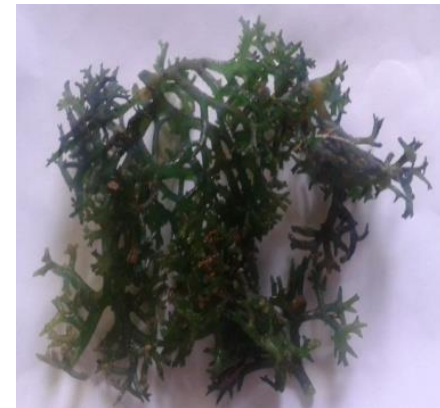

Eucheuma striatum

\section{Gambar 1. Sampel Alga Merah (Rhodophyta) Hasil Budidaya di Perairan Sreweh}

Secara morfologi terlihat bahwa ketiga spesies Eucheuma tersebut memiliki perbedaan pada warna dan bentuk thallus. Hal ini diduga karena dipengaruhi oleh kandungan pigmen pada thallus ketiga spesies tersebut. Lee (2008) menyatakan bahwa kenampakan warna talus yang bervariasi pada alga merah disebabkan adanya komposisi pigmen yang terdiri dari klorofil $a$, klorofil $d$, dan fikobiliprotein (R-fikosianin, allofikosianin serta fikoeritrin). Keseimbangan antara klorofil dan fikobiliprotein akan memberikan berbagai variasi warna pada thallusrumput laut mulai dari warna merah muda hingga keunguan (Aungtonya dan Liao, 2002).

Secara umum terlihat bahwa warna thallus alga merah E. cottonii dan E. spinosum tidak jauh berbeda, yaitu berwarna coklat kemerahan tetapi ukuran thallus alga merah $E$. cottonii lebih besar daripada E. spinosum. Sementara warna thallus E. striatum sangat berbeda dengan kedua sampel Eucheuma yang lainnya, yaitu lebih berwarna hijau dan percabangan thallusnya lebih kecil dibandingkan E. cottonii dan E. spinosum. Diduga bahwa habitat hidup spesies $E$. Striatum ketika di laut cenderung mendapatkan sinar matahari yang lebih tinggi sehingga warna thallusnya didominasi oleh pigmen klorofil yang memberikan warna hijau. Aungtonya and Liao (2002) menyatakan bahwa pada spesies rumput laut yang tumbuh di tempat yang mendapatkan intensitas cahaya matahari yang tinggi maka kandungan klorofilnya akan dominan dan menyebabkan rumput laut menjadi lebih hijau.

Karakteristik komposisi kimia dari ketiga spesies alga merah E. cottonii, E. spinosum dan E. striatum hasil budidaya di perairan Sreweh menunjukkan nilai yang bervariasi (Tabel 1.). Secara umum terlihat bahwa alga merah E. cottonii memiliki kandungan lemak, serat dan karbohidrat yang paling tinggi. Alga merah E. spinosum memiliki kadar air yang paling tinggi, dan E. striatum memiliki kandungan protein dan abu yang paling tinggi. Komposisi kimia ketiga spesies Eucheuma ini dapat bervariasi disebabkan oleh beberapa faktor lingkungan yang meliputi suhu air, salinitas, cahaya dan nutrisi, jenis, letak geografis serta musim (Ratana-arporn dan Chirapart 2006 ; Khairy dan El-Shafay, 2013).

Tabel 1. menunjukkan bahwa rata-rata kandungan kadar air alga merah $E$. cottonii, $E$. spinosum dan E. striatum dari perairan Sreweh berkisar antara 15,94-29,72\%. Semua alga merah yang digunakan pada penelitian ini berumur panen sekitar 42 hari. Menurut SNI 1992 kadar air maksimal rumput laut Eucheuma sp kering adalah 35\%. Dengan demikian maka kadar air semua spesies Eucheuma yang diuji pada penelitian ini masih memenuhi standar mutu rumput laut 
kering. Kadar air sangat berhubungan dengan mutu rumput laut. Sifat higroskopis pada rumput laut menyebabkan ketika penyimpanan pada tempat lembab dapat menyebabkan rumput laut cepat rusak apabila kadar airnya masih di atas 35\%.

Tabel 1. Komposisi kimia alga merah E. cottonii, E. spinosum dan E. striatum dari perairan Sreweh, Lombok Timur, NTB

\begin{tabular}{lcccccc}
\hline \multirow{2}{*}{ Spesies } & \multicolumn{5}{c}{ Komposisi Kimia Proksimat (\%)(berat kering) } \\
\cline { 2 - 7 } & Protein & \multicolumn{1}{c}{ Lemak } & Serat & Abu & Air & Karbohidrat \\
\hline E. cottonii & $3,11 \pm 0,005$ & $5,77 \pm 0,006$ & $15,22 \pm 0,044$ & $27,28 \pm 0,056$ & $16,48 \pm 0,142$ & $47,36 \pm 0,012$ \\
E. spinosum & $3,40 \pm 0,001$ & $3,58 \pm 0,0004$ & $12,59 \pm 0,027$ & $23,28 \pm 0,265$ & $29,72 \pm 0,093$ & $40,02 \pm 0,289$ \\
E. striatum & $4,51 \pm 0,007$ & $3,94 \pm 0,025$ & $11,98 \pm 0,027$ & $32,49 \pm 0,009$ & $15,94 \pm 0,035$ & $43,12 \pm 0,037$ \\
\hline
\end{tabular}

Kadar protein dari ketiga spesies Eucheuma pada penelitian ini berkisar antara 3,11-4,51\%. Protein pada rumput laut meskipun hanya terdapat dalam jumlah yang kecil, namun memiliki keunggulan yaitu kandungan asam amino esensialnya yang tinggi, seperti lisin, fenilalanin, metionin, leusine dan valin (Ortiz et al. 2006) dan komposisi asam amino pada rumput laut lebih lengkap jika dibandingkan dengan tumbuhan terestrial. Protein juga dapat berperan dalam kemampuan fisika - kimia seperti pada WHC (water holding capacity) (Wong dan Cheung 2000).

Kandungan lemak dari rumput laut tidak terlalu tinggi jika dibandingkan dengan tumbuhan terestrial. Rata-rata kadar lemak dari ketiga spesies Eucheuma pada penelitian ini berkisar antara 3,58-5,77\%. Menurut Khairy dan El-Shafay (2013) bahwa beberapa alga coklat, merah, dan hijau memiliki kadar lemak kurang dari $4 \%$ berdasarkan berat kering. Walaupun kandungan lemaknya kecil namun lemak pada alga merupakan sumber asam lemak $\omega-3$, seperti asam eikosapentaenoik - EPA (C20:5w3) dan asam dokosaheksaenoik -DHA (C20:6w3) (Polat dan Ozogul, 2013). Asam lemak ini merupakan asam lemak esensial bagi tubuh manusia yang dapat berperan sebagai antioksidan (Mendis dan Kim, 2011).

Kandungan karbohidrat merupakan komposisi kimia yang paling tertinggi pada ketiga spesies Eucheuma pada penelitian ini yang berkisar antara 40,02-47,36\%. Diharmi dan Irasari 2020 menyatakan bahwa karbohidrat pada alga merah mengandung polisakarida yang terdiri atas amilopektin glukan (tepung floridea). Polisakarida pada rumput laut dapat berperan sebagai sumber serat yang baik bagi pencernaan manusia (dietary fiber) (Dawczynski et al., 2007). Hasil penelitian ini menunjukkan bahwa rata-rata kandungan serat dari ketiga spesies Eucheuma ini berkisar antara 11,98-15,22\%. Kandungan serat kasar yang bervariasi sangat dipengaruhi oleh proses fotosintesis, pertumbuhan dan musim. Perubahan musim dapat menyebabkan perubahan kondisi lingkungan yang mempengaruhi proses fotosintesis dan penyerapan nutrien (Siddique, 2013; Wong dan Cheung, 2000).

Kadar abu merupakan kandungan total mineral yang dikandung oleh suatu bahan. Ketiga spesies Eucheuma pada penelitian ini memiliki nilai kadar abu berkisar antara 23,28 _ $32,49 \%$.Nilai kadar abu ini sejalan dengan pernyataan Venugopal (2011) yang menyatakan bahwa mayoritas nilai nutrisi kadar abu yang ada di rumput laut adalah antara $8,4-43,6 \%$ berat kering.Kadar abu rumput laut cukup tinggi karena rumput laut mengandung mineral-mineral baik yang makro dan mikroserta trace elemen (Matanjun et al., 2009; Mayer et al., 2011)

Hasil analisis kandungan pigmen klorofil dan fikoeritrin pada alga merah $E$. cottonii, $E$. spinosum dan E. striatum dapat dilihat pada Tabel 2. Hasil perhitungan menunjukkan bahwa kandungan klorofil a pada alga merah berkisar antara 3,35-30,41 $\mathrm{mg} / \mathrm{g}$, klorofil b berkisar antara 3,13-54,95 $\mathrm{mg} / \mathrm{g}$ dan fikoeritrin berkisar antara 15,11-42,88 $\mathrm{mg} / \mathrm{g}$ (Tabel 2.). Alga merah $E$. striatum memberikan kandungan klorofil a dan b yang tertinggi, sementara alga merah $E$. cottonii memberikan kandungan pigmen fikoeritrin yang tertinggi (Gambar 2).

Perbedaan kandungan pigmen klorofil dan fikoeritrin pada ketiga spesies alga merah Eucheuma tersebut didukung oleh warna thallusnya secara morfologi. Warna thallus $E$. cottonii dan E. spinosum berwarna coklat kemerahan karena kandungan pigmen fikoeritrin yang lebih banyak, sementara warna thallus $E$. striatum lebih berwarna hijau karena kandungan pigmen klorofil yang lebih banyak (Gambar 1.). Lee (2008) menyatakan bahwa alga merah mempunyai kenampakan warna talus yang bervariasi. Warna talus yang bervariasi disebabkan adanya komposisi pigmen yang terdiri dari klorofil $a$, klorofil $d$, dan fikobiliprotein (R-fikosianin, 
allofikosianin serta fikoeritrin). Fikoeritrin merupakan pigmen dominan pada alga merah dibandingkan dengan pigmen lainnya. Fikoeritrin dapat menutupi warna hijau dari klorofil dan warna biru dari fikosianin sehingga menyebabkan warna talus pada alga berwarna merah

Tabel 2. Klorofil a, Klorofil b dan Fikoeritrin Alga Merah E. cottonii, E. spinosum dan E. striatum dari Perairan Sreweh, Lombok Timur, NTB

\begin{tabular}{cccc}
\hline Sampel & Klorofil a $(\mathrm{mg} / \mathrm{g})$ & Klorofil b $(\mathrm{mg} / \mathrm{g})$ & Fikoeritrin $(\mathrm{mg} / \mathrm{g})$ \\
\hline E. cottonii & $4,15 \pm 0,83$ & $3,13 \pm 2,41$ & $42,88 \pm 2,55$ \\
E. spinosum & $3,35 \pm 1,63$ & $3,76 \pm 1,95$ & $27,88 \pm 2,66$ \\
E. striatum & $30,41 \pm 1,12$ & $54,95 \pm 2,85$ & $15,11 \pm 1,44$ \\
\hline
\end{tabular}

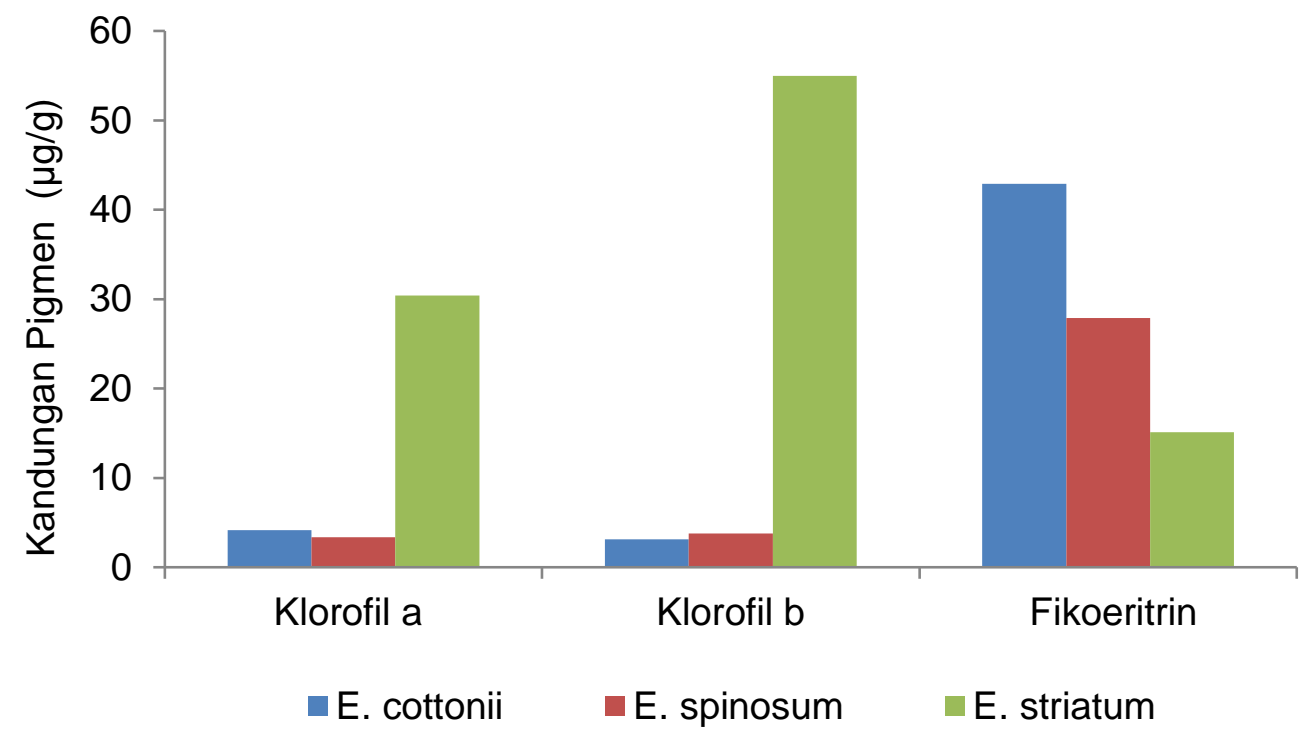

Gambar 2. Kandungan Pigmen Fotosintesis Alga Merah E. cottonii, E. spinosum dan E. striatum dari Perairan Sreweh, Lombok Timur, NTB

Pigmen klorofil pada alga merah tidak hanya berperan pada kenampakan warna thallus tetapi juga dapat mempengaruhi pertumbuhan alga melalui proses fotosintesis. Lumbessy et al., (2018) menyatakan bahwa pertumbuhan rumput laut berhubungan dengan pigmen fotosintesis. Jika penyerapan cahaya yang dilakukan oleh klorofil a mencukupi maka proses fotosintesis akan berlangsung optimal sehingga pertumbuhan rumput laut dapat meningkat. Sementara itu fikoeritrin (PE) merupakan protein yang bekerja sebagai pigmen pelengkap pada algae merah dan alga biru-hijau yang berfungsi untuk membantu klorofil-a dalam menyerap cahaya pada proses fotosintesis. Cahaya yang diserap oleh fikoeritrin secara efisiensi dipindahkan ke fikosianin, kemudian ke allofikosianin, diteruskan ke allofikosianin B dan terakhir ke klorofil (Chakdar dan Pabbi, 2012; Pugalendren et al., 2012).

Dewasa ini pemanfaatan pigmen klorofil dan fikoeritrin mulai dikembangkan sebagai produk pigmen alami yang berperan sebagai suplemen kesehatan. Klorofil yang diproduksi oleh beberapa spesies alga merah tidak hanya berpotensi untuk dikembangkan menjadi pewarna makanan yang aman bagi manusia, tetapi juga memiliki manfaat fungsional kesehatan yang penting, yaitu dapat digunakan sebagai bahan utama untuk terapi fotodinamik melawan kanker (Indriatmoko et al., 20015). Sementara itu Pumas et al. (2012) menunjukkan bahwa fikoeritrin merupakan pigmen yang berguna bagi kesehatan. Berdasarkan hasil uji menggunakan metode DPPH (2,2-difenil-1pikrilhidrazil) fikoeritrin berpotensi sebagai antioksidan. Pigmen tersebut dapat memperlambat bahkan menghambat oksidasi suatu zat, dapat melindungi sel dari dampak serangan radikal 
bebas. Selain sebagai antioksidan juga berpotensi sebagai pewarna alami dan label fluorensi yang dapat stabil pada suhu tinggi.

\section{KESIMPULAN}

Perbedaan spesies dapat mempengaruhi komposisi kimia dan pigmen fotosintesis pada berbagai alga merah hasil budidaya di laut. Alga merah E. cottonii memiliki kandungan lemak $(5,77 \%)$, serat $(15,22 \%)$, karbohidrat $(47,36 \%)$ dan pigmen fikoeritrin $(42,88 \mathrm{mg} / \mathrm{g})$ yang paling tinggi. Alga merah E. Spinosum mempunyai kadar air yang tertinggi $(29,72 \%)$, dan $E$. striatummemiliki kandungan protein $(4,51 \%)$, abu $(32,49 \%)$, klorofil a $(30,41 \mathrm{mg} / \mathrm{g})$ dan klorofil b $(54,95 \mathrm{mg} / \mathrm{g})$ yang paling tinggi

\section{UCAAN TERIMA KASIH}

Penelitian ini didukung oleh sumber dana DIPA BLU Skema Penelitian Peningkatan Kapasitas, Universitas Mataram Tahun Anggaran 2020 dengan nomor kontrak : 2730 / UN18.L1 / PP / 2020

\section{DAFTAR PUSTAKA}

[AOAC] Association of Official Analytical Chemist. 2006. Edisi Revisi. Edisi 18 2005. Official Methods of Analysis. Washington DC

Aguilera, J., Bischof, K., Karsten, U., Hanelt, D. \& Wiencke, C. 2002. Seasonal Variation in Ecophysiological Patterns in Macroalgae from an Arctic Fjord. II. Pigment Accumulation and Biochemical Defence Systems Against High Light Stress. Marine Biology, 140:1087-1095.

Aungtonya, C. \& Liao, L.M. 2002. Marine Flora (Algae and Seagrasses) in The Reference Collection of the Phuket Marine Biological Center, Thailand. Phukety Marine Biological Center Research Bulletin, 64:65-80

Beer, S., \& Eshel, A. 1985. Determining Phycoerythrin and Phycocyanin Concentrations in Aqueous Crude Extracts of Red Algae. Marine and Freshwater Research, 36:785-792

Bixler, H.J. \& Porse, H. 2011. A Decade of Change in the Seaweed Hydrocolloids Industry. Journal of Applied Phycology, 23(3):321-335.

Chakdar, H., \& Pabbi, S. 2012. Extraction and Purification of Phycoerythrin From Anabaena variabilis (CCC421). Phykos, 42(1):25-31.

Dawczynski C., Schubert, R. \& Jahreis, G. 2007. Amino Acid, Fatty Acid, and Dietary Fibre in Edible Seaweed Products. Food chemistry, 103:891-9. DOI: 10.1016/j.foodchem.2006.09. 041

de Fretes, H., Susanto, A.B., Limantara, L., Prasetyo, B., Heriyanto \& Brotosudamo, T.H.P. 2011. Composition and Content of Pigment, Photostability and Thermostability Studies of Crude Pigment Extracts from Red, Brown and Green Varieties of Red Algae Kappaphycus alvarezii (Doty) Doty. Seminar ICONS, Universitas Ma Chung, Malang.

Diharmi, A. \& Irasari, N. 2020. Characteristic of Carrageenan Eucheuma cottonii Collected from the Coast of Tanjung Medang Village and Jaga Island, Riau. IOP conference Series : Earth and Environmental Science. 404:012049.

Ferawati, E., Widyartini, D.S. and Insan, I., 2014. Studi Komunitas Rumput Laut Pada Berbagai Substrat di Perairan Pantai Permisan Kabupaten Cilacap. Scripta Biologica, 1(1), pp.57-62.

Gudrun, K. \& Wincke, C. 2005. Photosynthesis, Photosynthetic Pigment andMycosporine-Like Aminoacids After Exposure of the Marine Red Alga Chondrus crispus (Gigartinales, Rhodophyta) to Different Light Qualities. Phycologia, 44(1):95-102

Holdt S.L., \& Kraan, S. 2011. Bioactive Compounds in Seaweed: Functional Food Applications and Legislation. Journal of Applied Phycology, 23(3):543-97. DOI: 10.1007/s10811-010-96 32-5

Indriatmoko, H., Limantara, L. \& Brotosudarmo, T.P., 2015. Composition of Photosynthetic Pigments in A Red Alga Kappaphycus alvarezi Cultivated in Different Depths. Procedia Chemistry, 14:193-201 
Kumar, V. \& Kaladharan, P. 2007. Amino Acids in the Seaweeds as an Alternate Source of Protein for Animal Feed. Journal of the Marine Biological Association of India, 49(1):35-40.

Khairi, H.M. \& El Shafay, S.M. 2013. Seasonal Variations in the Biochemical Compositionof Some Common Seaweed Species from the Coast of Abu Qir Bay, Alexandria, Egypt. Oceanologia, 55(2):435-452. DOI: 10.5697/oc.55-2.435

Lee, R.E. 2008. Phycology. Fouth Edition. Cambridge University Press. http:/www.cambridge.org/ 97805621864084. Diakses pada tanggal 21 Februari 2020.

Lumbessy, S.Y., Andayani, S., Nursyam, H. \& Firdaus, M. 2018. Concentration of Liquid Pes Media on The Growth and Photosynthetic Pigments of Seaweeds Cotonii Propagule (Kappaphycus Alvarezii Doty) Through Tissue Culture. Russian Journal of Agricultural and Socio-Economic Sciences, 3(75):133-144

Lumbessy, S.Y., Andayani, S., Nursyam, H. \& Firdaus, M. 2019. Biochemical Study of Amino Acid Profile of Kappaphycus alvarezii and Gracilaria Salicornia Seaweeds from Gerupuk Waters, West Nusa Tenggara (NTB). EurAsian Journal of Biosciences, 13:303-307.

Madhavarani, A \& Ramanibai, R. 2014. In-vitro Antibacterial Activity of Kappaphycus alvarezii Extracts Collected from Mandapam Coast, Rameswaram, Tamil Nadu. International Journal of Innovative Research in science, Engineering and Techhnology, 3(1):2319-8753

Matanjun, P., Mohamed, S., Mustapha, N.M. \& Muhammad, K. 2009. Nutrient Content of Tropical Edible Seaweeds, Eucheuma cottonii, Caulerpa lentillifera, and Sargassum polycystum. Journal of Applied Phycology, 21(1):75-80.

Mayer, A.M.S., Rodriguez, A.D., Berlinck, R.G.S. \& Fusetani, N. 2011. Marine Compounds with Antibacterial, Anticoagulant, Antifungal, Anti-Inflammatory, Antimalarial, Antiprotozoal, Antituberculosis, and Antiviral Activities; Affecting the Immune and Nervous System,and Other Miscellaneous Mechanisms of Action. Comparative Biochemistry and Physiology. 153:191222.

Mendis, E., \& Kim, S.K. 2011. Present and Future Prospects of Seaweeds in Developing Functional Foods. Advances in Food and Nutrition Research,64:1-15

Merdekawati, W. \& Susanto, A.B. 2009. Kandungan dan Komposisi Pigmen Rumput Laut serta Potensinya untuk Kesehatan. Squalen, 4(2):41-47.

Naguit, M.R.A. \& Tisera, W.L. 2009. Pigment Analysis on Eucheuma denticulatum(Collins \& Hervey) and Kappaphycus alvarezii (doty) Cultivars Cultured at DifferentDepths. Threshold, 4:29-37.

Nurjanah, N.M., Anwar, E., Luthfiyana, N. \& Hidayat, T., 2017. Identification of Bioactive Compounds of Seaweed Sargassum sp. and Eucheuma cottonii doty as a Raw Sunscreen Cream. Proceedings of The Pakistan Academy of Sciences : B. Life and Evironmental Sciences. 54(4):311-318.

Benjama, O. \& Masniyom, P. 2012. Biochemical Composition and Physicochemical properties of two Red Seaweeds (Gracilaria fisheri and G. tenuistipitata) from the Pattani Bay in Southern Thailand. Songklanakarin Journal of Science and Technology, 34(2):223-230.

Ortiz, J., Romero, N., Robert, P., Araya, J., Lopez-Hernández, J., Bozzo, C., Navarrete, E., Osorio, A. and Rios, A. 2006. Dietary Fiber, Amino Acid, Fatty Acid and Tocopherol Contents of the Edible Seaweeds Ulva lactuca and Durvillaea antartica. Food chemistry, 99(1):98-104. DOI : 10.1016/j.foodchem.2005.07.027

Polat, S., \& Ozogul, Y. 2009. Fatty Acid, Mineral and Proximate Composition of Some Seaweeds from the Northeastern Mediterranean Coast. Italian Journal of Food Science, 21(3):317-324.

Pugalendren S., Sarangam, B. \& Rengasamy, R. 2012. Extraction of R-Phycoerythrin from Kappaphycus alvarezii (Doty) Doty ex Silva and Analyses of its Physico-Chemical Properties. Journal of Academia and Industrial Research, 1(7):407-411

Pumas, C., Peerapornpisal, Y., Vacharapiyasophon, P., Leelapornpisid, P., Boonchum, W., Ishii, M. and Khanongnuch, C., 2012. Purification and characterization of a thermostable phycoerythrin from hot spring cyanobacterium Leptolyngbya sp. KC45. International Journal of Agriculture and Biology, 14(1):121-125.

Ratana-arporn, P. \& Chirapart, A 2006. Nutritional Evaluation of Tropical Green Seaweeds Caulerpa lentillifera and Ulva reticulate. Kasetsart Journal, 40(Suppl.):75-83 
Reeta, J. \& Kulandaivelu, G. 2000. Effect of Light Intensity on the Saturation ofPhotosynthesis in Gracilaria Species (Rhodophyta). Seaweed Research Utilization,22(1\&2):31-35

Sarojini Y.K., and Narayanan, L. 2009. Influence of Environmental Factors on Variationsin Distribution of Photosynthetic Pigments of Macro Algae. Algal Biomass Resources and Utilization:157-163

Schmidt, E.C., Nunes, B.G., Maraschin, M. \& Bouzon, Z.L. 2010. Effect of Ultraviolet-B Radiation on Growth, Photosynthetic Pigment, and Cell Biology of Kappaphycusalvarezii(Rhodophyta, Gigartinales) Macroalgae Brown Strain. Photosynthetica, 48(2):161-172.

Siddique M.A.M., Khan, M.S.K. \& Bhuiyan, M.K.A. 2013. Nutritional Composition and Amino Acid Profile of a Sub-Tropical Red Seaweed Gelidium pusillumCollected from St. Martin's Island, Bangladesh. International Food Research Journal, 20(5): 2287-92. DOI: 10.3153/jfscom. 2013018

SNI 01-2690. 1992. Rumput laut kering. Jakarta; Dewan standarisasi Naional hal, 1-7.

Sterman, T.N. 1988. Spectrophotometric and Fluorometric Chlorophyll Analysis. In: Lobban, S. C., D.J. Chapman and B. P. Kremer. Experimental Phycology, A Laboratory Manual Cambridge University Press. New York. Pp. 35-39.

Vanitha, A. \& Chandra, S. 2012. Studies on Photosynthetic Pigments of Some RedAlgae of Covelong, Chennai (India). International Journal of Current Science, p149-154.

Venugopal, V. 2011. Polysaccharides from Seaweed and Microalgae Marine Polysaccharides Food Applications. Boca Raton, USA: CRC Press.p.89-129.

Wong K.H. \& Cheung, P.C.K. 2000, Nutritional Evaluation of Some Subtropical Red and Green Seaweeds. Part I. Proximate Composition, Amino Acid Profiles and Some Physico-Chemical Properties. Food Chemistry, 71(4):475-482, DOI: 10.1016/S0308-8146(00)00175-8.

Xiren G.K, \& Aminah, A. 2017. Proximate Composition And Total Amino Acid Composition of Kappaphycus alvareziFound in the Waters of Langkawi and Sabah, Malaysia. International Food Research Journal, 24(3):1255-60.

Zawawi M.H., Idris, M.H., Kamal, A.H.M. \& King, W.S 2014. Seaweed Composition from Bintulu Coast of Sarawak, Malaysia. Pakistan Journal of Biological Sciences, 17(8):1007-1014. DOI: 10.3923/pjbs.2014.1007.1014 